\title{
Interaction of Calcium Ion with Bovine Caseins
}

\author{
Tamotsu IMAdE, * Yasushi SATo and Hajime NoguchI \\ Department of Food Science and Technology, Faculty of Agriculture, \\ Nagoya University, Nagoya 464, Japan \\ Received April 28, 1977
}

\begin{abstract}
In order to clarify the interaction of calcium ion with casein, the volume change associated with the interaction was measured by dilatometric procedures. When $\mathrm{CaCl}_{2}$ was added to the casein solutions at neutral $\mathrm{pH}$, a volume increase occurred and reached a constant saturated value of about $700 \mathrm{ml}$ per $10^{5} \mathrm{~g}$ protein with increasing $\mathrm{CaCl}_{2}$ concentrations for whole-, $\alpha_{\mathrm{B}}$ - and $\beta$-casein solutions, but there was no volume change for $\kappa$-casein solution. On the other hand, the binding of calcium ion to the casein fractions was determined by a gel filtration procedure at $\mathrm{pH} 6.0$ to 9.0. The number of $\mathrm{Ca}^{2+}$ ions bound to the caseins increased with the $\mathrm{CaCl}_{2}$ concentration and $\mathrm{pH}$ value, and the relative order of binding capacities for the caseins was: $\alpha_{\varepsilon}$-casein $>$ whole-casein $>\beta$-casein $>\kappa$-casein.

It was found that the volume changes obtained by the dilatometry were smaller than the calculated volume increases based on the assumption that these are caused by the binding of $\mathrm{Ca}^{2+}$ ion to the caseins. Therefore it is necessary to introduce another factor which reduces the volume increase due to the $\mathrm{Ca}^{2+}$ ion binding in order to reasonably explain the measured volume changes. At present it is presumed that there occurs the unfolding of peptide chain of casein molecule on $\mathrm{Ca}^{2+}$ ion binding, which has been known to decrease the volume of the protein solution.
\end{abstract}

The interactions of caseins with mono- and di-valent cations have been extensively studied for several decades. Especially the calcium binding to casein molecules has been elucidated by many investigators as it is closely connected with the formation of casein micelles. Studies on the formation and structure of casein micelles have been comprehensively reviewed by Waugh. ${ }^{1)}$ However, the relation between the ion binding to caseins and the micelle formation of caseins does not yet seem to have been completely solved.

One of the authors pursued the globular protein to fibrous protein transition (G-F transition) of actin and flagellin molecules by dilatometry and analyzed the polymerization phenomenon from the viewpoint of the formation of intermolecular hydrophobic bonding between them. ${ }^{2,3}$ This procedure is very valid for study of ion-protein or proteinprotein interactions as a volume change as-

* On leave from Department of Food Science, Faculty of Agriculture, Kagawa University, Miki-cho, Kagawa 761-07 (1973 1974). sociated with the interactions always takes place and it concerns the characteristic property of the interaction.

A simple and precise gel filtration method was introduced by Hummel and Dreyer ${ }^{4}$ to determine the amount of ion bound to protein molecule, and has been extensively applied for the study of the binding of small molecules to protein. ${ }^{5}$ We also applied this method to determine the amount of $\mathrm{Ca}^{2+}$ ion bound to soybean $11 \mathrm{~S}$ protein and a satisfactory result was obtained $;^{6}$ then the procedure was again used to detect the degree of $\mathrm{Ca}^{2+}$ ion binding to the casein molecules.

\section{MATERIALS AND METHODS}

Preparation of materials. Whole-casein was prepared from unpasteurized skim milk by acidification as described by Hipp et al., ${ }^{7)} \alpha_{s}$-casein and $k$-casein were prepared by the procedure described by Tsugo and Yamauchi, ${ }^{8)}$ which is essentially the same as the procedure of Long et al.$^{9)}$ except for the additional treatment of $\alpha_{\mathrm{S}}$-casein at a higher alkalinity prior to the addition of calcium chloride, and $\beta$-casein was 
prepared by the method of Hipp et al. ${ }^{10)}$

The purified water passed through a mixed-bed ionexchange resin was distilled with an all pyrex glass distillatory apparatus and then used throughout the preparation of caseins and the measurements. As we intended to clarify the interactions of caseins with calcium ion, it was necessary to check the content of the ion, which was expected to exist in the casein molecules, in advance of the measurements. Calcium determination was made by a flame analysis using an atomic absorption spectrophotometer (Hitachi Model 208). The result indicated that the contents of calcium existing in the casein molecules were negligibly little (see Table I).

Table I. $\mathrm{Ca}^{2+}$ Ion Existing in Prepared Casein Molecules

\begin{tabular}{rr} 
Casein & $\mathrm{Ca}^{2+}$ mole $/ 10^{5}$ g casein \\
\hline Whole-casein & 0.56 \\
$\alpha_{s}$-Casein & 0.70 \\
$\beta$-Casein & 0.65 \\
$\kappa$-Casein & 1.57 \\
\hline
\end{tabular}

Dilatometry. The volume change that accompanied the interaction of calcium ion and casein molecule was measured with a Carlsberg type dilatometer described in the previous paper. ${ }^{11}$ All measurements were carried out at $25.00^{\circ} \mathrm{C}$ in a thermostated water bath with the allowance of $\pm 0.0002^{\circ} \mathrm{C}$. One arm of the $\mathrm{V}$ tube was filled with $5 \mathrm{ml}$ of $0.5 \%$ casein solution at $\mathrm{pH} 6.9$ and $0.07 \mathrm{M} \mathrm{KCl}$, and the other with $5 \mathrm{ml}$ of $0.07 \mathrm{M} \mathrm{KCl}$ solution, containing a varying amount of $\mathrm{CaCl}_{2}$, at $\mathrm{pH}$ 6.9. Details of the measurements were described in the previous paper., ${ }^{8,11}$

By dilatometry, the volume change upon mixing of casein and $\mathrm{CaCl}_{2}$ solutions can be directly measured even if there appears precipitation or aggregation in the mixing solution. On the other hand, if we measure the densities of casein, $\mathrm{CaCl}_{2}$ and the mixing solutions separately, the volume change on mixing casein and $\mathrm{CaCl}_{2}$ solutions can be easily calculated. Now we can use a very precise densitimeter (Anton Parr, DMA$02 \mathrm{C})$ to measure the density of solution with an accuracy of $\pm 2 \times 10^{-8} \mathrm{~g} / \mathrm{ml}$. Therefore, the volume change associated with the interaction of casein and calcium ion was also determined with the densitimeter, but we cannot apply the apparatus to measure a solution density if there is precipitation or aggregation.

Gel filtration. Gel filtration was carried out on a Sephadex $G-25$ coarse column $(0.9 \times 60 \mathrm{~cm}$ bed) equilibrated with a buffer containing a desired $\mathrm{CaCl}_{2}$ concentration. When the protein binds calcium ion, the solvent of this sample will be depleted with respect to calcium ion. The resulting elution profile exhibits a peak in calcium ion concentration above the calcium ion-saturated base- line. This peak represents the excess calcium ion bound, and a corresponding trough, which represents the depletion that resulted when the bound calcium ion was carried ahead with the casein, will follow. In principle, the areas of trough and peak are qual. From the area and the known concentration of casein applied, the binding ratio is determined corresponding to the calcium ion saturated level used. Casein concentration was determined by a dry method, and calcium concentration was measured by flame spectrophotometry. The concentration of $1 \mathrm{mM} \mathrm{Ca}{ }^{2+}$ ion was determined with an error of about $1 \%$ that is, the error was about \pm 1 mole $\mathrm{Ca}^{2+} / 10^{5} \mathrm{~g}$ casein for the elute protein solution of $1 \mathrm{mg} / \mathrm{ml}$.

\section{RESULTS AND DISCUSSION}

Figure 1 shows the volume changes, $\Delta V$, observed during the addition of $\mathrm{CaCl}_{2}$ to wholecasein solution at $\mathrm{pH} 6.9$ and $0.07 \mathrm{M} \mathrm{KCl}$, and

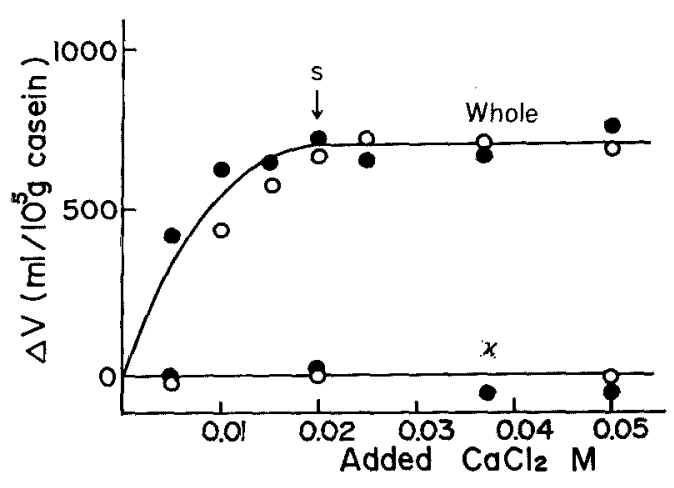

Fig. 1. Volume Changes of Whole-casein and $\kappa$ Casein during Titration with $\mathrm{CaCl}_{2}$ at $\mathrm{pH} 6.9$ and $25^{\circ} \mathrm{C}$.

$\mathrm{O}$, obtained by dilatometer; $\mathbf{0}$, obtained by densitimeter; s, saturation point.

the calculated volume changes of the same system obtained with the densitimeter. The value of volume changes is recognized to be completely reliable as these two sets of measured values coincide very well with each other. The volume increment accompanying the interaction of $\mathrm{CaCl}_{2}$ with casein molecules is saturated at $0.02 \mathrm{M} \mathrm{CaCl}_{2}$. Similar volume changes were observed for $\alpha_{\mathrm{s}^{-}}$and $\beta$-casein plus $\mathrm{CaCl}_{2}$ systems. In the case of these systems, there appeared white coagulations upon addition of $\mathrm{CaCl}_{2}$, and then it was im- 
possible to measure the $\Delta V$ with the Anton Parr densitimeter. When $\mathrm{CaCl}_{2}$ was added to $\kappa$-casein solution there was no volume change as indicated in Fig. 1; it therefore seems that there is no interaction between $\mathrm{CaCl}_{2}$ and $\kappa$-casein.

As described in another paper, ${ }^{6)}$ it has been recognized that the volume change upon mixing of protein solution with another containing some chemical is caused by the following factors, (i) neutralization of ionized groups on protein molecule with counterions, which accompanies the volume increase, (ii) polymerization or aggregation of protein molecules that causes a positive volume change of a few hundred milliliters per mole of protein, ${ }^{2,3,6)}$ and (iii) protein denaturation associated with a volume decrease of several hundred mililiters per $10^{5} \mathrm{~g}$ of protein. ${ }^{12,13)}$

Volume changes due to the interaction of $\mathrm{CaCl}_{2}$ with casein molecules, except for $\kappa$ casein, reach a finite saturated value at a given concentration of $\mathrm{CaCl}_{2}$. If it is assumed that the volume changes are only due to the charge neutralization of $\mathrm{Ca}^{2+}$ ion bound to the protein, we can calculate the maximum amount of $\mathrm{CaCl}_{2}$ interacting with casein molecules from these saturated $\mathrm{CaCl}_{2}$ concentrations, and at the same time the volume increase per mole of casein molecule can be determined. In Table II the results are given.

The table indicates that (i) the maximum moles of bound $\mathrm{Ca}^{2+}$ ion per mole of casein molecule are much larger than the values reported by several authors ${ }^{14 \sim 16)}$ or the values obtained by our gel filtration, (ii) the volume increments, about $2 \mathrm{ml} /$ mole of bound $\mathrm{Ca}^{2+}$, due to the neutralization reaction are much smaller than the values obtained for the reaction of $\mathrm{Ca}^{2+}$ ion with carboxylate or phosphate ions (see later discussion), and (iii) the result that the volume increase for $\alpha_{\mathrm{s}}$ - and $\beta$-casein are almost the same cannot be explained only by the charge neutralization of $\mathrm{Ca}^{2+}$ ion with the negative charges on the protein, as it was reported that there was a big difference in moles of negative charge per mole of $\alpha_{\mathrm{s}^{-}}$and $\beta$-casein molecules. ${ }^{16)}$

From the above discussion, it is clear that these volume increases are not caused only by the $\mathrm{Ca}^{2+}$ ion binding to the negative charges on the casein molecules. Though the $\mathrm{Ca}^{2+}$ ion binding to casein molecules has been studied extensively, there is a considerable discrepancy between the reported number of $\mathrm{Ca}^{2+}$ ions and the casein molecules. Then we tried to precisely determine the amount of bound $\mathrm{Ca}^{2+}$ ion to the molecules by the gel filtration method. Figure 2 shows the result of binding measurement on a $0.5 \mathrm{ml}$ solution containing $10 \mathrm{mg}$ whole-casein, $1 \mathrm{~mm}$

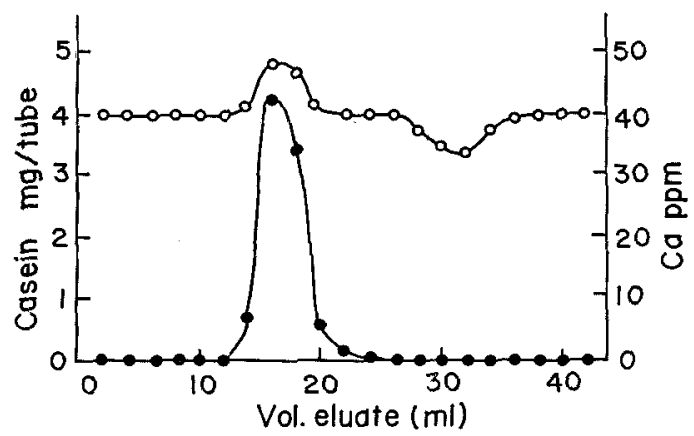

Frg. 2. Elution Profile of $\mathrm{Ca}^{2+}$ Ion Compared with That of Whole-casein at $\mathrm{pH} 7.0$.

Gel filtration was carried out at a flow rate of $15 \mathrm{ml}$ per hour.

$O, \mathrm{Ca}^{2+}$ ion concentration;

casein concentration.

Table II. Maximum Moles of $\mathrm{CaCl}_{2}$ Reacted with Casein in pH 6.9 and $0.07 \mathrm{M} \mathrm{KCl}$ Solution, and Volume Increment Obtained upon Mixture of $\mathrm{CaCl}_{2}$ and Casein at $25^{\circ} \mathrm{C}$

\begin{tabular}{cccc} 
Casein & $\begin{array}{c}\text { Reacted } \mathrm{CaCl}_{2} \\
\text { moles } / 10^{5} \mathrm{~g} \text { of protein }\end{array}$ & $\begin{array}{c}\mathrm{Max} \Delta V \\
\mathrm{ml} / 10^{5} \mathrm{~g} \text { of protein }\end{array}$ & $\begin{array}{c}\begin{array}{c}\Delta V \\
\mathrm{ml} / \mathrm{Ca}^{2+} \mathrm{mole}\end{array} \\
\text { Whole-casein }\end{array}$ \\
$\begin{array}{c}\alpha_{\mathrm{a}} \text {-Casein } \\
\beta \text {-Casein }\end{array}$ & 1200 & 680 & 2.3 \\
$\kappa$-Casein & 1200 & 680 & 1.7 \\
& 0 & 700 & 1.8 \\
\hline
\end{tabular}


$\mathrm{CaCl}_{2}, 0.01 \mathrm{M}$ Tris- $\mathrm{HCl}$ and $0.07 \mathrm{M} \mathrm{KCl}$ at $\mathrm{pH} 7.0$ by gel filtration. The elution profile exhibits a peak and through representing the existence of $\mathrm{Ca}^{2+}$ ions bound to protein. From the area of the trough and the mole of the casein applied, the number of $\mathrm{Ca}^{2+}$ ions bound to protein was estimated to be $8 \pm 1$ moles of $\mathrm{Ca}^{2+} / 10^{5} \mathrm{~g}$ of whole-casein. The same elution measurements were done for all casein solutions containing various concentrations of $\mathrm{CaCl}_{2}$ at $\mathrm{pH} 6.0$ to 9.0. Summaries of the results are shown in Figs. 3, 4, 5 and 6

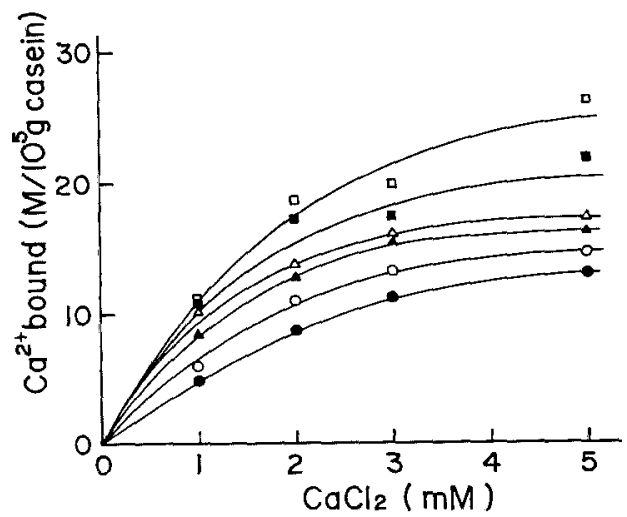

FIG. 3. $\mathrm{Ca}^{2+}$ Ion Bound to Whole-casein in $0.01 \mathrm{M}$ Tris- $\mathrm{HCl}$ and $0.07 \mathrm{M} \mathrm{KCl}$.

○, pH $6.0 ; 0$, pH $6.5 ; \Delta, \mathrm{pH} 7.0 ; \Delta, \mathrm{pH} 7.5$; pH $8.0 ; \square, \mathrm{pH} 9.0$.

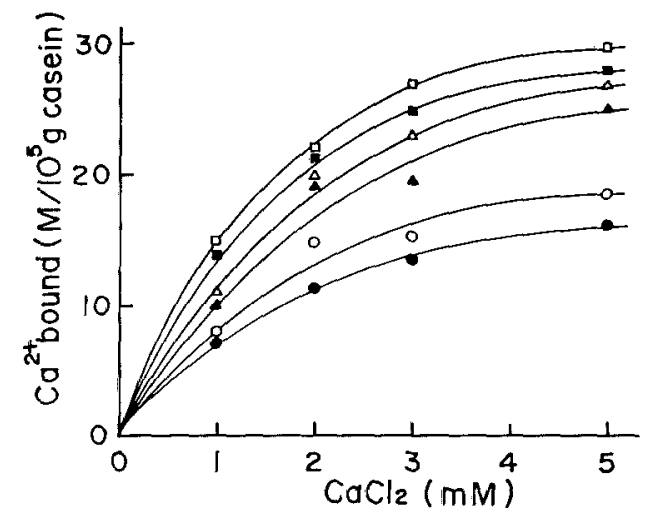

FIG. 4. $\mathrm{Ca}^{2+}$ Ion Bound to $\alpha_{\mathrm{s}}$-Casein in $0.01 \mathrm{M}$ Tris- $\mathrm{HCl}$ and $0,07 \mathrm{M} \mathrm{KCl}$

Notation for $\mathrm{pH}$ is the same as in Fig. 3 .

for whole-casein, $\alpha_{\mathrm{s}}$-casein, $\beta$-casein and $\kappa$ casein, respectively. On the other hand we

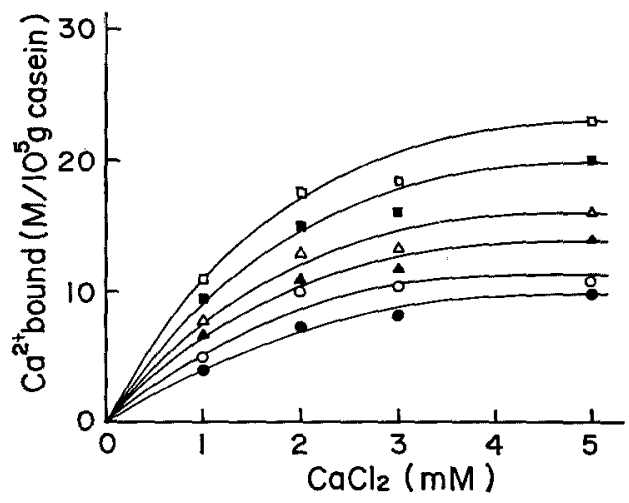

FIG. 5. $\mathrm{Ca}^{2+}$ Ion Bound to $\beta$-Casein in $0.01 \mathrm{M}$ Tris$\mathrm{HCl}$ and $0.07 \mathrm{M} \mathrm{KCl}$.

Notation for $\mathrm{pH}$ is the same as in Fig. 3.

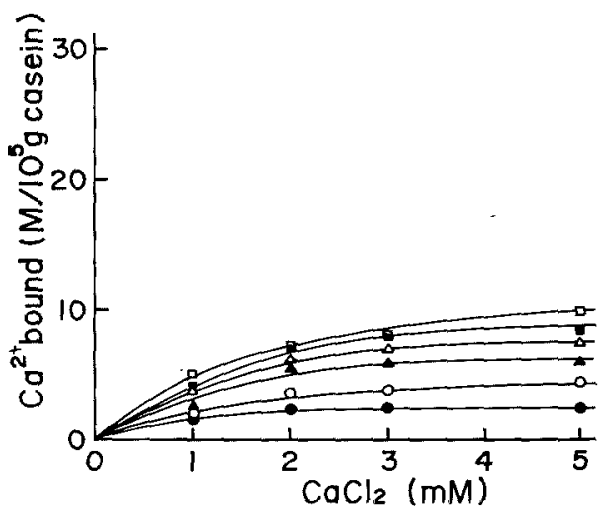

FIG. 6. $\mathrm{Ca}^{2+}$ Ion Bound to $\kappa$-Casein in $0.01 \mathrm{M}$ Tris$\mathrm{HCl}$ and $0.07 \mathrm{M} \mathrm{KCl}$.

Notation for $\mathrm{pH}$ is the same as in Fig. 3.

determined the amount of bound $\mathrm{Ca}^{2+}$ ion to caseins by this method for casein solutions at $\mathrm{pH} 6.7$ to $7.0,0.07 \mathrm{M} \mathrm{KCl}$, and a $\mathrm{CaCl}_{2}$ concentration less than $3 \mathrm{~mm}$. The results indicated the binding number of $\mathrm{Ca}^{2+}$ ion to casein molecules was almost the same as in Tris- $\mathrm{HCl}$ buffer solutions within the experimental error.

Binding of $\mathrm{Ca}^{2+}$ to caseins increases as the free $\mathrm{Ca}^{2+}$ ion concentration is raised and the caseins are precipitated or aggregated at a higher concentration than $5 \mathrm{mM}$ except for $\kappa$-casein; so the gel filtration procedure was applied to $5 \mathrm{mM} \mathrm{CaCl}$ in Tris- $\mathrm{HCl}$ buffer solutions. The relative order of binding capacities for $\mathrm{Ca}^{2+}$ ion to casein fractions is: $\alpha_{s}$ - 
casein $>$ whole-casein $>\beta$-casein $>\kappa$-casein, which is the same as that determined by Dickson and Perkins. ${ }^{15}$ ) The moles of bound $\mathrm{Ca}^{2+}$ per $10^{5} \mathrm{~g}$ casein at $\mathrm{pH} 7.4$ (Tris- $\mathrm{HCl}$, $\mathrm{I}=0.1$ ) determined by them using equilibrium dialysis for $\alpha_{\mathrm{s} 1^{-}}$-casein, $\beta$-casein and $\kappa$-casein fairly well coincided with ours. The effect of $\mathrm{pH}$ on the binding of $\mathrm{Ca}^{2+}$ to casein is also seen from the figures. The result that the binding of $\mathrm{Ca}^{2+}$ ion increased with the $\mathrm{pH}$ is also similar to their finding.

Now we must interpret the mechanism of the interaction between $\mathrm{Ca}^{2+}$ ion and casein molecule based on the results of both the gel filtration and the volume change. The volume changes associated with the binding of $\mathrm{Ca}^{2+}, \mathrm{Mg}^{2+}$ and $\mathrm{Ba}^{2+}$ ions to synthetic polyelectrolytes have been elucidated by several authors. $\left.{ }^{17} 20\right) \quad$ According to Strauss and Leung, ${ }^{17}$ ) the binding of $\mathrm{Mg}^{2+}$ ion to carboxylate ion causes a volume increase of $26 \mathrm{ml}$ per mole of $\mathrm{Mg}^{2+}$ ion. The volume increase due to $\mathrm{Ca}^{2+}$ ion binding to carboxylate and phosphate ions was estimated to be nearly the same. Therefore, the volume increase caused by the $\mathrm{Ca}^{2+}$ ion bound to protein at $\mathrm{pH} 6.9$ and $0.07 \mathrm{M} \mathrm{KCl}$ can be readily calculated for each casein fraction, and the values and observed ones in $5 \mathrm{mM} \mathrm{CaCl}_{2}$ solution at $\mathrm{pH} 6.9$ and $0.07 \mathrm{M} \mathrm{KCl}$ are given in Table III. The amounts of $\mathrm{Ca}^{2+}$ ion bound to protein in the solution are also given.

From the table it is clear that the observed volume changes are much smaller than the calculated ones. Therefore, it is impossible to attribute the volume changes to only the charge neutralization reaction of bound $\mathrm{Ca}^{2+}$ ion with the negative charges on the protein molecules.
On the other hand, we measured the volume change when $\mathrm{Mg}^{2+}, \mathrm{Sr}^{2+}$ and $\mathrm{Ba}^{2+}$ ions were added to whole-casein solution at $\mathrm{pH} 6.9$ and $0.07 \mathrm{M} \mathrm{KCl}$. The results are shown in Fig. 7 .

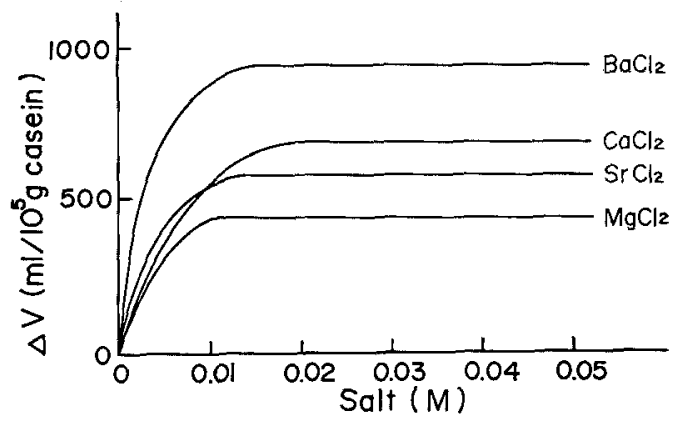

FIG. 7. Volume Change of Whole-casein during Titration with $\mathrm{MgCl}_{2}, \mathrm{SrCl}_{2}, \mathrm{CaCl}_{2}$ and $\mathrm{BaCl}_{2}$ at $\mathrm{pH}$ $6.9,0.07 \mathrm{M} \mathrm{KCl}$ and $25^{\circ} \mathrm{C}$.

According to Dickson and Perkins there are differences in the amount of individual alkalin-earth-metal ions bound to $\alpha_{\mathrm{si}}$-casein and $\beta$-casein fractions, and the relative order of binding capacities to either is $\mathrm{Mg}^{2+}>\mathrm{Ca}^{2+}$ $>\mathrm{Ba}^{2+}>\mathrm{Sr}^{2+}$. As the volume increases owing to the binding of $\mathrm{Mg}^{2+}, \mathrm{Ca}^{2+}$ and $\mathrm{Ba}^{2+}$ ions to negative charges on casein molecules are the same (we have no data on $\mathrm{Sr}^{2+}$ ), the order of volume change for the individual cations must be the same as the above order, but the result is just the opposite. This is another definite evidence that the volume changes are not only due to the charge neutralization of the cations by the negative charges on casein molecules.

One of the authors measured the volume change associated with the G-F transition of flagellin and action. In the flagellin solution the volume increment of $400 \mathrm{ml} / 10^{5} \mathrm{~g}$ of

Table III. amounts of $\mathrm{Ca}^{2+}$ Ion Bound to Casein and $\Delta V$ at pH 6.9 and $5 \mathrm{~mm} \mathrm{CaCl}_{2}$

\begin{tabular}{cccc} 
Casein & $\begin{array}{c}\text { Moles of } \mathrm{Ca}^{2+} / 10^{5} \mathrm{~g} \\
\text { casein }\end{array}$ & $\begin{array}{c}\Delta V \text { calculated by } \\
\text { (mole of } \mathrm{Ca}^{2+} \text { bound } \\
\times 25) \mathrm{ml} / 10^{5} \mathrm{~g} \text { of protein }\end{array}$ & $\begin{array}{c}\Delta V \text { obtained by } \\
\text { dilatometry } \\
\mathrm{ml} / 10^{5} \mathrm{~g} \text { of protein }\end{array}$ \\
\hline $\begin{array}{c}\text { Whole-casein } \\
\alpha_{\mathrm{g}} \text {-Casein } \\
\beta \text {-Casein }\end{array}$ & 16 & 400 & 300 \\
$\kappa$-Casein & 25 & 350 & 250 \\
& 14 & 130 & 130 \\
\hline
\end{tabular}


flagellin was observed at $25^{\circ} \mathrm{C}$, and in the case of actin the volume increase of $690 \mathrm{ml} / 10^{\delta} \mathrm{g}$ of actin was observed after correction for such factors as the volume increase due to the binding of ATP and $\mathrm{Mg}^{2+}$ ion. Recently, the volume increase of about $650 \mathrm{ml} / 10^{5} \mathrm{~g}$ of protein was obtained when $\mathrm{CaCl}_{2}$ was added to soybean $11 \mathrm{~S}$ protein solution at $\mathrm{pH} 6.8$ where it is considered that $\mathrm{Ca}^{2+}$ ion does not bind to the protein. ${ }^{6)}$ From these results, the volume increase is recognized to take place when the aggregation or polymerization of protein molecules occurs.

In the case of caseins, except for $\kappa$-casein, since coagulation or precipitation occurs when alkalin-earth-metal cations are added to the protein solution, the excess volume increase in the order of several hundred milliliters must be added upon mixing of the protein with the cations. However, as the observed volume changes were much smaller than the expected values, it must be concluded that there exists another factor which reduces the volume increase. As explained before, it has been noticed that protein denaturation causes the volume decrease of several hundred milliliters per $10^{5} \mathrm{~g}$ of protein. This volume decrease is considered due to the transition of the secondary structure of the peptide chain to a coiled form, ${ }^{11}$ the rupture of intramolecular hydrophobic bonds and the disappearance of the void volume in the protein. It is therefore presumed that the unfolding of the polypeptide chain or the conformational change of casein molecules occurs when $\mathrm{Ca}^{2+}$ ions bind to them, resulting in a volume decrease of the protein solution. The hydrophobic groups on the peptide chain come out as a result of the unfolding of the protein molecule, and the unfolded protein molecules interact each other through the hydrophobic groups; that is, there occurs the intermolecular hydrophobic bonding and the coagulation or precipitation takes place. The presumption that the conformational change of casein molecules is induced by the bound $\mathrm{Ca}^{2+}$ ions is not absurd as it was reported that one subunit of troponin $\left(\mathrm{Ca}^{2+}\right.$ binding component) bound $\mathrm{Ca}^{2+}$ ion and a striking change in conformation of the component was introduced. ${ }^{21}$

As a whole the neutralization reaction with negative charges on protein, the conformational change of the protein and the formation of intermolecular hydrophobic bonding take place when $\mathrm{CaCl}_{2}$ is added to the casein solutions. These reactions are completed before a given $\mathrm{CaCl}_{2}$ concentration is added, then the volume increase reaches a saturated constant value at this critical concentration of $\mathrm{CaCl}_{2}$.

The purified casein components were reported to undergo endothermic associations. In the case of $\alpha_{\mathrm{s} 1}$-casein, ${ }^{22)}$ it was found that the average molecular weight rapidly increased with concentration and also with temperature at $\mathrm{pH}$ 6.4. On the other hand, $\beta$-casein exists in the monomeric state at $4^{\circ} \mathrm{C}$, and it strongly polymerizes at a higher temperature. ${ }^{23)}$ Therefore we have investigated the interaction of associated casein molecules and $\mathrm{Ca}^{2+}$ ions, but it is advisable to pursue the interaction of $\mathrm{Ca}^{2+}$ ion with monomeric casein molecule to clarify the mechanism of the micelle formation of casein molecules. Then, there still remain many difficulties to be overcome in order to reach a final conclusion on the mechanism of the micelle formation of casein molecules by the addition of $\mathrm{CaCl}_{2}$.

This work was supported by Grants 943017 and 847085 from the Ministry of Education, Science and Culture of Japan.

\section{REFERENCES}

1) D. F. Waugh, "Milk Protein," ed. by H. A. McKenzie, Vol. II, Academic Press, New York, 1971, p. 3.

2) T. Ikkai, T. Ooi and H. Noguchi, Science, 152, 1756 (1966).

3) B. R. Gerber and H. Noguchi, J. Mol. Biol., 26, 197 (1967).

4) J. P. Hummel and W. J. Dreyer, Biochim. Biophys. Acta, 63, 530 (1962).

5) G. C. Wood and P. G. Cooper, Chromatogr. Rev., 12, 88 (1970).

6) M. Sakakibara and H. Noguchi, Agric. Biol. Chem., in press. 
7) N. J. Hipp, M. L. Groves, J. H. Custer and T. L. McMeekin, J. Am. Chem. Soc., 72, 4928 (1950).

8) T. Tsugo and K. Yamauchi, Bull. Agric. Chem. Soc. Jpn, 24, 96 (1960).

9) J. Long, Q. Van Winkle and I. A. Grould, J. Dairy Sci., 41, 317 (1958).

10) N. J. Hipp, M. L. Groves, J. H. Custer and T. L. McMeekin, ibid., 35, 272 (1952).

11) H. Noguchi and J. T. Yang, Biopolymers, 1, 359 (1963).

12) R. B. Simpson and W. Kauzmann, J. Am. Chem. Soc., 75, 5139 (1953).

13) P. A. Charlwood, ibid., 79, 776 (1957).

14) C. A. Zittle, E. S. Dellamonica, R. K. Rudd and J. H. Custer, Arch. Biochem. Biophys., 76, 342 (1958).
15) I. R. Dickson and D. J. Perkins, Biochem. J., 124, 235 (1971).

16) D. F. Waugh, C. W. Slattery and L. K. Creamer, Biochemistry, 10, 817 (1971).

17) U. P. Strauss and Y. P. Leung, J. Am. Chem. Soc., 87, 1476 (1965).

18) A. J. Begala and U. P. Strauss, J. Phys. Chem., 76, 254 (1972).

19) J. Hen and U. P. Strauss, ibid., 78, 1013 (1974).

20) F. Delben and S. Paolletti, ibid., 78, 1486 (1974).

21) J. P. van Eerd and Y. Kawasaki, Biochem. Biophys. Res. Commun., 47, 859 (1972).

22) T. A. J. Payens and D. G. Schmidt, Biochim. Biophys. Acta, 109, 214 (1965).

23) T. A. J. Payens and B. W. Van Markwijk, ibid., 71, 517 (1963). 